\title{
PEMANFAATAN BARANG BEKAS LAYAK PAKAI SEBAGAI ALAT PERAGA BAHASA DI TK WISATA KUMARA DAN TK KUMARA KERTI
}

\author{
oleh, \\ Ni Luh Putu Sri Adnyani, I Made Suta Paramarta, Putu Suarcaya \\ Fakultas Bahasa dan Seni \\ Universitas Pendidikan Ganesha
}

\begin{abstract}
ABSTRAK
Kegiatan pengabdian pada masyarakat yang berjudul "Pemanfaatan Barang Bekas Layak Pakai sebagai Alat Peraga Bahasa di TK Wisata Kumara dan TK Kumara Kerti" merupakan sebuah kegiatan pelatihan yang diberikan kepada guru-guru TK yang bertujuan untuk Adapun tujuan darai pelaksanaan kegiatan P2M ini adalah: 1)Untuk meningkatkan kuantitas dan kualitas alat peraga bahasa kelompok Taman Kanak-Kanak Wisata Kumara dana Kumara Kerti, 2) untuk meningkatkan variasi atau keberagaman alat peraga bahasa yang dimiliki TK-TK tersebut, dan 3) untuk membantu guru dalam upaya pencapaian standar perkembangan bahasa anak melalui alat peraga bahasa yang memadai. Kegiatan telah dilaksanakan pada bulan September 2013. Pada kegiatan tersebut alat peraga yang dihasilkan adalah buku berbincang dan kartu memori.
\end{abstract}

Kata-kata kunci: barang bekas, alat peraga bahasa, TK

\begin{abstract}
Community service activities, entitled "Utilization of Used Goods in circulation as a Tool for Language Modeling in TK and TK Kumara Kumara Travel Kerti" is a training activities provided to kindergarten teachers who aim to darai The purpose of conducting the $\mathrm{P} 2 \mathrm{M}$ are: 1) to improve the quantity and quality of language groups props Kindergarten Kerti Travel Kumara Kumara funds, 2) to increase the variation or diversity props language is owned kindergartens, and 3) to assist teachers in achieving the standards of language development of children through props adequate language. Activities have been carried out in September 2013. In the event, the props are produced book talk and memory card.
\end{abstract}

Keywords: thrift, props language, TK

\section{Pendahuluan}

Di Desa Kalibukbuk dan Desa Anturan yang secara geografis letaknya bersebelahan terdapat masing-masing satu buah Penyelenggara PAUD jalur pendidikan formal berbentuk Taman Kanak Kanak (TK) yang dikelola oleh ibu -ibu PKK desa setempat. Kedua TK tersebut, yaitu TK Wisata Kumara dan TK Kumara Kerti. 
Berdasarkan informasi yang diperoleh dari kepala sekolah kedua TK tersebut, mereka mengalami kekurangan sarana dan prasarana yang mendukung proses pendidikan dan bermain anak. Mereka mengandalkan sumbangan yang dipungut dari orang tua siswa, yang rata-rata berjumlah Rp 120.000,- pertahun peranak. Pada tahun ajaran 2011/2012, setiap TK memiliki rata-rata 70 orang anak didik dengan sebaran $10 \%$ penitipan anak, $30 \%$ TK A dan 60\% TK B. Dengan jumlah anak yang cukup banyak, setiap TK hanya memiliki dana alat pertahun rata-rata sebesar Rp 8.400.000,- dari sumbangan orang tua anak. Jumlah ini, sangat minim dibandingkan dengan kebutuhan anak akan alat-alat yang dapat membantu mereka dalam mengenyam proses pendidikan usia dini.

Observasi di lapangan menunjukkan bahwa ruang kelas TK belum dilengkapai dengan alat-alat peraga yang memadai begitu juga dengan alat peraga yang menunjang keterampilan berbahasa anak. TK Wisata Kumara memiliki dua buah ruang kelas dan TK Kumara Kerti memiliki tiga buah ruang kelas. Setiap ruang kelas hanya dilengkapi dengan beberapa buah meja dan kursi, sebuah lemari, sebuah meja guru, sebuah papan tulis dan poster-poster dari kertas yang ditempel di dinding kelas.

Ironisnya, Desa Kalibukbuk dan Desa Anturan adalah desa-desa yang terkenal dengan daerah pariwisata pantainya yang cukup terkenal, yaitu kawasan wisata Lovina. Di daerah wisata ini terdapat berbagai hotel dan restoran yang memiliki berbagai limbah pariwisata, misalnya berupa majalah-majalah bekas yang sering ditinggalkan wisatawan setelah selesai dibaca, brosur-brosur yang sudah tidak terpakai, koran-koran baik yang internasional maupun lokal serta barang-barang bekas lain baik berupa botol plastik yang berwarna warni, kaleng-kaleng dari berbagai merek serta kardus-kardus bekas pembungkus barang bahkan pakaian bekas yang begitu saja dionggokkan oleh para wisatawan di tong sampah dengan alasan sudah aus atau karena para wisatawan tersebut ingin mengurangi beban kopernya yang sering sudah dipenuhi dengan barang-barang souvenir yang telah dibeli di daerah wisata.

Tragisnya, barang-barang bekas tersebut masih layak pakai dan sering memiliki kualitas yang baik namun dibuang begitu saja. Barang-barang bekas layak pakai tersebut sebenarnya bisa dimanfaatkan sebagai bahan dasar untuk membuat alat alat peraga bahasa yang dapat membantu anak dalam meningkatkan keterampilan berbahasa mereka. Berbagai majalah bekas yang ditinggalkan oleh para wisatawan sangat 
bervariasi dan sering dipenuhi dengan foto-foto objek yang sangat menarik. Ambillah satu contoh majalah yang berhubungan dengan olah raga air seperti menyelam. Jenis majalah ini memuat berbagai foto kekayaan flora dan fauna alam bawah laut. Majalah lain, misalnya yang berhubungan dengan budaya yang sering memuat temapat-tempat bersejarah atau foto-foto warisan sebuah budaya, sangat disayangkan jika nasib dari majalah-majalah bekas tersebut terangkut bersama mobil dinas pekerjaan umum pengangkut sampah. Selama ini belum disadari oleh pihak pengelola TK desa setempat untuk memanfaatkan barang bekas layak pakai yang dihasilkan pelaku pariwisata sebagai alat peraga atau media pembelajaran yang menunjang proses pendidikan dan bermain anak.

Memang saat ini seiring dengan berkembangnya pendidikan anak usia dini berbagai alat peraga dan media pembelajaran yang dapat membantu proses pendidikan di TK sudah banyak yang diproduksi produsen apalagi di kota-kota besar. Namun untuk sebuah TK yang hanya dikelola oleh sekumpulan ibu-ibu PKK di desa Kalibukbuk dan desa Anturan dengan dana yang dialokasikan untuk alat dengan jumlah yang sangat terbatas, alat-alat peraga tersebut cucup mahal untuk mereka jangkau. Di samping itu, lokasi TK tersebut berada dengan jarak $10 \mathrm{~km}$ dari kota terdekat, yaitu Singaraja. Sementara di kota Singaraja hanya terdapat dua buah toko buku yang lebih mengutamakan untuk menjual buku-buku pelajaran untuk anak SD, SMP, dan SMA. Toko-toko buku tersebut jarang menyediakan alat-alat peraga yang dapat digunakan anak usia dini dalam mengembangkan kreatifitas mereka. Untuk mendapatkan alat-alat peraga yang beraneka ragam, guru-guru TK harus mencarinya di pusat kota Denpasar yang berjarak sekitar $80 \mathrm{~km}$ dari Singaraja. Selain itu, pun jika para guru berkeinginan untuk ke Denpasar untuk membeli alat-alat peraga tersebut, dana yang mereka miliki sebagian besar akan habis untuk transportasi yang juga jatuhnya cukup mahal. Dengan kenyataan itu, alat-alat peraga bisa dibuat sendiri oleh para guru dengan memanfaatkan limbah pariwisata yang sering masih memiliki kualitas yang baik dan layak pakai.

Adapun tujuan darai pelaksanaan kegiatan P2M ini adalah: 1)Untuk meningkatkan kuantitas dan kualitas alat peraga bahasa kelompok Taman Kanak-Kanak Wisata Kumara dana Kumara Kerti, 2) untuk meningkatkan variasi atau keberagaman alat peraga bahasa yang dimiliki TK-TK tersebut, dan 3) untuk membantu guru dalam upaya 
pencapaian standar perkembangan bahasa anak melalui alat peraga bahasa yang memadai.

\section{Metode Pelaksanaan Pengabdian}

Dalam kegiatan pengabdian ini, masalah yang akan ditangani adalah kurangnya alat peraga bahasa/media pembelajaran dengan membuat/menciptakan alat peraga dengan memanfaatkan barang bekas dari sisa kegiatan pariwisata. Masalah ini dapat diatasi dengan memberikan pelatihan bagi guru-guru TK yang seluruhnya berjumlah 12 orang. Alat-alat peraga yang dapat dibuat dari barang bekas yang terkumpul adalah Panel Teksipel, flash cards, kartu memori, 'buku berbincang' dan poster-poster pembelajaran.

Pelatihan ini sangat mungkin untuk dilakukan karena: (1) bahan baku berupa barang bekas dengan kualitas yang masih baik sangat berkelimpahan dan mudah didapat, hanya diperlukan pendekatan dan kerjasama dengan pihak pelaku pariwisata seperti hotel, restoran, dive center dll., (2) pelatih/instruktur adalah dosen-dosen dari fakultas bahasa dan seni Universitas pendidikan Ganesha, (3) pembuatan alat peraga bahasa/media pembelajaran ini bukan termasuk kegiatan yang padat modal karena sebagaian besar memanfaatkan barang-barang bekas yang mudah didapat, (4) Alat peraga/media pembelajaran yang dihasilkan sangat menunjang pendidikan anak usia dini dan mengingkatkan kreativitas para guru dalam membimbing anak. Rencana pemecahan masalah yang dibuat dalam pelatihan ini secara rinci adalah: (a) Instruktur bersamasama dengan guru TK menghubungi pihak pelaku pariwisata pemilik hotel, restoran, dive center, SPA untuk mendapatkan barang bekas yang masih memiliki kualitas yang baik seperti majalah, koran brosur bekas, botol, dan kardus, (b) Barang-barang yang terkumpul diklasifikasikan, gambar-gambar yang terdapat dalam koran, brosur dan majalah dikumpulkan berdasarkan empat tema besar, yaitu flora, fauna, alam benda, dan manusia, (c) Pelatihan membuat Panel Teksipel (flanel board). Untuk membuat panel teksipel diperlukan papan dari triplek. Papan dibungkus dengan kain flanel. Gambargambar yang telah digunting di belakangnya diperkuat dengan guntingan kardus yang dilekati dengan guntingan kertas amplas. Kertas amplas ini berfungsi untuk merekatkan gambar ke papan yang telah dibungkus dengan kain flannel sehingga berbagai gambar bisa dipasang dan dibuka lagi, (d) Pelatihan pembuatan Flash cards (kartu bergambar) dibuat dengan berbagai ukuran sesuai dengan gambar yang diperoleh dari majalah atau 
Koran bekas. Misalnya satu set kartu dibuat dengan topik alat-alat transportasi. Setiap alat transportasi yang ditemukan digunting, ditempel ke kertas kardus lalu dibungkus dengan plastik bening. Berbagai kartu dengan bergaia topik bisa dibuat, (e) Pelatihan pembuatan Kartu memori. Kartu memori dibuat dengan membuat sepasang kartu yang memiliki gambar yang mirip atau identis. Kartu juga dibuat dari gambar yang diperkuat belakangnya dengan kertas kardus bekas. Dengan kartu ini anak bisa memasangkan kartu atau mencari pasangan kartu untuk melatih daya ingat serta kemampuan kognitif mereka, (f) Pelatihan membuat 'buku berbincang'. Disebut 'buku berbincang' karena dengan buku ini anak-anak bisa diajak bercakap-cakap oleh guru. Buku ini dibuat dengan bahan dasar kertas manila berwarna putih yang gigunting dan dibentuk seperti buku dengan ukuran $25 \mathrm{~cm}$ x $20 \mathrm{~cm}$. Setiap halaman ditempel berbagai macam gambar dengan karakteristik tertentu. Misalnya dalam satu halaman ada enam buah gambar. Beberapa dari gambar tersebut sengaja ditempel dengan posisi terbalik. Dengan halaman tersebut guru bisa bertanya kepada murid "Coba sebutkan gambar apa yang terbalik?" Dihalaman lain bisa disusun gambar-gambar dari yang berukuran kecil sampai besar. Dengan halaman ini, guru bisa bertanya kepada murid "Benda apa yang paling kecil atau yang paling besar?” Anak juga bisa menggunakan buku tersebut secara berpasangan, saling bertanya dan menjawab, dan (g) Pelatihan membuat poster-poster dengan topik tertentu. Misalnya poster tentang anggota keluarga, yaitu membuat pohon keluarga, peta sebuah desa atau kota dengan bangunan-bangunan yang ada. Dengan peta tersebut anak bisa diajarkan tentang arah dan bagaimana caranya pergi ke suatu tempat.

Metode/pendekatan yang ditawarkan untuk membantu guru-guru TK dalam meningkatkan keterampilan berbahasa anak adalah dengan memberikan pelatihan untuk membuat/menciptakan alat peraga bahasa/media pembelajaran secara mandiri. Dalam membuat alat-alat peraga tersebut yang terbuat dari barang bekas, instruktur terdiri dari dosen-dosen dari fakultas bahasa dan seni serta. Proses pembuatan alat peraga tersebut diharapkan juga dapat meningkatkan kreativitas guru dan wawasan bahwa alat peraga tidak selalu harus dibeli namun juga dapat memanfaatkan barang bekas yang sering terdapat di lingkungan tempat tinggal terlebih lagi di lingkungan pariwisata seperti lingkungan tempat kedudukan TK Wisata Kumara dan TK Kumara Kerti. 


\section{Hasil Dan Pembahasan}

Kegiatan pengabdian pada masyarakat yang dikemas dalam bentuk pelatihan pembuatan alat peraga bahasa dengan memanfaatkan barang bekas layak pakai di TK Wisata Kumara yang berkedudukan di Desa Kalibukbuk dan TK Kumara Kerti di Desa Anturan, Kecamatan Buleleng telah dilaksanakan pada Bulan September 2013. Pada pelaksanaan kegiatan tersebut, jumlah peserta yang hadir adalah 14 orang yang terdiri dari kepala Taman Kanak-kanak beserta guru-guru di kedua TK tersebut. Dalam pelaksanaan P2M, panitia juga dibantu oleh 4 (empat) orang mahasiswa Jurusan Bahasa inggris Diploma-3.

Kegiatan diawali dengan pemaparan tujuan kegiatan serta manfaat kegiatan dilaksanakan baik untuk Tk, guru-guru maupun anak-anak yang belajar di TK-Tk tersebut. Paparan kegiatan disampaikan oleh ketua panitia. Pelatihan pertama yang dilakukan adalah pelatihan pembuatan alat peraga bahasa berupa pembuatan "Buku Berbincang". Buku berbincang adalah buku yang disusun dengan menggunakan gambar-gambar yang diperoleh dari guntingan koran atau majalah yang diklasifikasi menjadi tema-tema tau topik-topik tertentu. Setiap gambar dilengkapi dengan teks-teks singkat yang bertujuan untuk menggali informasi dari para siswa TK. Misalnya, dalam topik " Cita-Cita" ada gambar-gambar yang berisi jenis-jenis pekerjaan. Dalam setiap gambar pekerjaan ada teks yang berisi kalimat-kalimat sederhana, misalnya "Siapa ingin jadi Pilot?" atau "Kalau sudah besar, kalian ingin jadi apa?" Teks-teks tersebut ditujukan untuk membantu guru untuk mengembangkan komunikasi dengan siswa melalui media gambar.

Gambar dan teks dicetak dan ditempel dalam kerta ukuran F4 yang kemudian dimasukkan ke dalam map yang memiliki folder plastik. Map ini sangat praktis untuk digunakan karena berbentuk seperti buku. Bungkus plastik didalamnya dapat melindungi kertas sehingga tidak mudah rusak dan tahan lama. Beberapa tema yang dibuat dalam buku berbincang adalah "Cita-Citaku", "Alat Transportasi", "Ayo Berlibur", "Olah raga" dan "makanan Kesukaan". Tema-tema yang dipilih adalah tematema yang lekat dengan kehidupan dan lingkungan anak . Hal ini bertujuan agar anak dapat memahami isi buku dengan mudah. Buku yang dihasilkan tidak dirancang agar anak bisa membaca buku tersebut, namun dirancang untuk menjalin komunikasi yang interaktif antara guru dan anak dan sesama anak. 
Pelatihan kedua yang dilaksanakan adalah pelatihan pembuatan kartu memori. Kartu memori merupakan salah satu alat peraga yang dapat digunakan baik untuk mengasah memori anak maupun keterampilan berbahasa. Kartu memori yang dibuat terdiri dari pasangan-pasangan gambar yang berukuran bujur sangkar dibuat dengan ukuran 4 x $4 \mathrm{~cm}$. Dengan kartu memori anak bisa bermain dan belajar. Pelatih juga menjelaskan cara penggunaan kartu memori. Kartu-kartu yang telah dibuat disebarkan di atas meja dengan posisi terbalik atau posisi gambar mengarah ke meja sehingga gambar tidak kelihatan oleh anak-anak yang bermain. Anak-anak duduk melingkar dan masing-masing anak mendapatkan kesempatan untuk mencari pasangan kartu secara bergiliran dengan cara mencoba membuka satu pasang kartu. Jika mereka tidak menemukan pasangan gambar yang sama, maka mereka harus meletakkan kartu tersebut kembali ke posisi semula. Juika mereka berhasil menemukan pasangan kartu, mereka berhak untuk mengambil pasangan kartu tersebut. Pemenangnya adalah anak yang berhasil mendapatkan pasangan kartu paling banyak. Kartu-kartu memori yang dibuat juga dilaminating. Hal ini bertujuan agar kart-kartu yang dihasilkan bisa bertahan lama dapat digunakan berulang-ulang tanpa khawatir kartu tersebut akan rusak dengan cepat.

Dalam pelaksanaan P2M ini, instruktur atau pelatih juga memberikan materi-materi tambahan yang dapat digunakan oleh guru sebagai bahan ajar dalam pembelajaran bahasa. Para guru TK sangat antusias mengikuti pelatihan dan semua guru mengikuti kegiatan dari awal sampai akhir. Pelaksanaan P2M ini juga melibatkan beberapa orang mahasiswa. Beberapa mahasiswa yang dilibatkan dalam pelaksanaan P2M ini merupakan mahasiswa yang berasal dari Jurusan Bahasa Inggris Diploma 3. Pelibatan mahasiswa bertujuan untuk memperkenalkan kepada mahasiswa tentang salah satu jenis kegiatan pengabdian pada masyarakat yang dapat dilaksanakan di luar kampus. Hal ini diharapkan untuk memberikan ide-ide segar kepada mahasiswa untuk mendorong mahasiswa memiliki kreativitas dalam menulis khususnya dalam penulisan sebuah kegiatan ilmiah.

Di samping memperkenalkan kepada mahasiswa tentang kegiatan-kegiatan ilmiah yang dapat dilaksanakan di luar kampus, pelibatan mahasiswa juga dapat mengurangi beban pelatih dalam pelaksanaan kegiatan. Kontribusi mahasiswa sangat besar karena 
mereka sangat membantu baik dalam persiapan pelaksanaan kegiatan maupun dalam pelksanaan kegiatan atau selama kegiatan berlangsung. Salah satu contoh, mereka mendampingi guru ketika pelatihan berlangsung serta mempersiapkan konsumsi baik bagi panitia maupun peserta pelatihan.

Dalam kegiatan pengabdian pada masyarakat ini, alat peraga yang dihasilkan baru berupa buku berbincang dan kartu memori. Sementara panek teksibel, flash cards dan poster belum terealisasi. Alat peraga bahasa yang belum sempat terselesaikan dalam kegiatan ini diharapkan akan bisa terlaksana pada program pengabdian pada masyarakat yang akan datang.

\section{Kesimpulan}

Kegiatan P2M yang dilaksanakan di TK Kumara Kerti dan TK Wisata Kumara yang masing-masing berkedudukan di Desa Anturan dan Desa Kalibukbuk merupakan sebuah kegiatan yang berusaha memanfaatkan penggunaan barang bekas sebagai alat peraga bahasa. Kegiatan telah dilaksanakan pada bulan September 2013 dengan format pelaksanaan menggunakan format pelatihan. Dalam kegiatan tersebut, alat peraga bahasa yang dihasilkan, yaitu "Buku Berbincang" dan kartu-kartu memori. Masingmasing TK menghasilkan satu buah produk buku berbincang dan satu set kartu memori yang terdiri dari 40 pasang kartu.

\section{DAFTAR PUSTAKA}

Desmita. 2009. Psikologi Perkembangan. Bandung: PT Remaja Rosdakarya.

Felicia, Nadia. 2011. Mengapa Pendidikan Anak Usia Dini Penting? http://female.kompas.com. Diunduh (25 Agustus 2012)

Peraturan Menteri Pendidikan Nasional Republik Indonesia Nomor 58 Tahun 2009

Taylor, Insup. 1990. Psycholinguistiks: Learning and Using Language. Englewood Cliffts: Prentice-Hall.Inc. 